\title{
Induced systemic resistance in cucumber and Arabidopsis thaliana by the combination of Trichoderma harzianum Tr6 and Pseudomonas sp. Ps14
}

\author{
Hamidreza Alizadeh a,b,c, Keivan Behboudi a , Masoud Ahmadzadeh ${ }^{a}$, Mohammad Javan-Nikkhah ${ }^{\text {a }}$, \\ Christos Zamioudis $^{\mathrm{b}}$, Corné M.J. Pieterse ${ }^{\mathrm{b}}$, Peter A.H.M. Bakker ${ }^{\mathrm{b}, *}$ \\ ${ }^{a}$ Department of Plant Protection, University College of Agriculture and Natural Resources, University of Tehran, Karaj 31587-77871, Iran \\ ${ }^{\mathrm{b}}$ Plant-Microbe Interactions, Department of Biology, Faculty of Science, Utrecht University, P.O. Box 800.56, 3508 TB Utrecht, The Netherlands \\ ${ }^{\mathrm{c}}$ Department of Plant Science, Faculty of Agriculture, University of Jiroft, P.O. Box 364, Jiroft, Iran
}

\section{H I G H L I G H T S}

Trichoderma and Pseudomonas strains were isolated from cucumber rhizosphere.

- Strains were tested for eliciting systemic resistance against Fusarium in cucumber.

- Combining Trichoderma and Pseudomonas leads to enhanced induced resistance.

- This enhanced effectiveness is observed in cucumber but not in Arabidopsis.

- In cucumber the enhanced effectiveness is paralleled by enhanced priming of defense genes.

\section{A R T I C L E I N F O}

\section{Article history:}

Received 27 September 2012

Accepted 28 January 2013

Available online 5 February 2013

\section{Keywords:}

Arabidopsis thaliana

Botrytis cinerea

Cucumber

Defense genes

Fusarium oxysporum f. sp. radicis

cucumerinum

Induced systemic resistance

Pseudomonas

Trichoderma

\section{G R A P H I C A L A B S T R A C T}

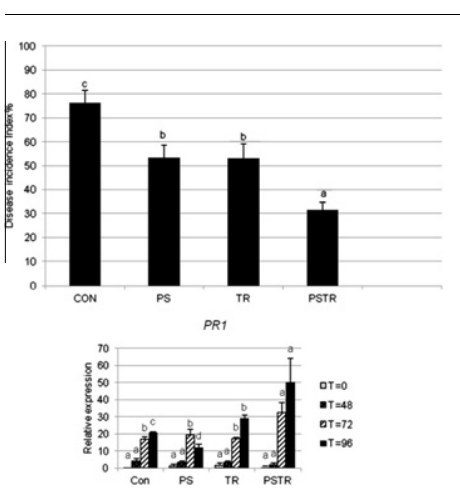

\begin{abstract}
A B S T R A C T
Trichoderma species and fluorescent Pseudomonas spp. have been reported to induce systemic resistance in plants. In this study the effectiveness of a combination of these biological control agents on the efficacy of induced resistance was investigated in cucumber and the model plant Arabidopsis thaliana. Trichoderma harzianum Tr6, and Pseudomonas sp. Ps14, both isolated from the rhizosphere of cucumber, were tested as a single application and in combination for their abilities to elicit induced resistance in cucumber against Fusarium oxysporum $\mathrm{f}$. sp. radicis cucumerinum and in A. thaliana against Botrytis cinerea. The combination of $\operatorname{Tr} 6$ and Ps 14 induced a significantly higher level of resistance in cucumber, which was associated with the primed expression of a set of defense-related genes upon challenge with Fusarium. In Arabidopsis both Ps14 and Tr6 triggered ISR against B. cinerea but their combination did not show enhanced effects. In the induced systemic resistance-defective Arabidopsis mutant myb72, none of the treatments protected against $B$. cinerea, whereas in the SA-impaired mutant sid2 all treatments were effective. Taken together, these results indicate that in Arabidopsis Ps14 and Tr6 activate the same signaling pathway and thus have no enhanced effect in combination. The enhanced protection in cucumber by the combination is most likely due to activation of different signaling pathways by the two biocontrol agents.
\end{abstract}

(c) 2013 Elsevier Inc. All rights reserved.

\section{Introduction}

The rhizosphere is a nutrient-rich habitat and harbors a large variety of bacteria and fungi that each can have neutral, beneficial

\footnotetext{
* Corresponding author.

E-mail address: p.a.h.m.bakker@uu.nl (P.A.H.M. Bakker).
}

or deleterious effects on the plant (Berendsen et al., 2012). Some of these organisms can improve plant growth by different mechanisms (Lugtenberg and Kamilova, 2009; Van der Ent et al., 2009b). Fluorescent Pseudomonas and Trichoderma species are important groups of plant growth-promoting microorganism reported to protect plants against pathogens by mechanisms such as antagonism, competition, and induced systemic resistance 
(ISR) (Harman et al., 2004a; Kloepper et al., 1980; Marx, 2004; Van Loon et al., 1998; Vinale et al., 2008). Rhizosphere colonization by certain plant growth-promoting rhizobacteria (PGPR) and fungi (PGPF) can elicit ISR (Bent, 2006; De Vleesschauwer and Höfte, 2009; Harman et al., 2004a; Kloepper et al., 1992; Shoresh et al., 2010; Van Loon et al., 1998; Van Wees et al., 2008). ISR triggered by PGPFs and PGPRs confers a broad-spectrum resistance that is effective against different types of attackers (De Vleesschauwer and Höfte, 2009; Van der Ent et al., 2009b).

Specific recognition between plants and ISR inducing organism appears to be required for the onset of ISR (Conrath et al., 2002). Rhizobacterial determinants that can elicit ISR include flagella, lipopolysaccharides, iron regulated metabolites, antibiotics, volatiles, phenolic compounds and quorum sensing molecules (Bakker et al., 2007; De Vleesschauwer and Höfte, 2009; Van Loon et al., 1998). Following perception of the inducer, plants activate a signal-transduction pathway in which phytohormones such as salicylic acid (SA), jasmonic acid (JA), ethylene (ET), and abscisic acid (ABA) are key signaling molecules (De Vleesschauwer and Höfte, 2009; Pieterse et al., 2009). Studies with Arabidopsis thaliana (Arabidopsis) mutants deficient in hormone-regulated signaling pathways and Pseudomonas fluorescens strain WCS417r demonstrated that in this combination ISR is SA-independent, but requires an intact response to ET and JA (Pieterse et al., 1998, 1996; Van Wees et al., 1997). The transcription factor MYB72 is an important factor in induced resistance by both $P$. fluorescens WCS417 and Trichoderma asperellum T34 and thus appears to be a common node in ISR by PGPR and PGPF (Segarra et al., 2009; Van der Ent et al., 2008).

Trichoderma spp. are plant symbionts that live free in the rhizosphere (Harman et al., 2004a). Presence of fungal prey and root derived nutrients are major attractants for Trichoderma spp. (Druzhinina et al., 2011). Trichoderma spp. can produce several plant defense eliciting MAMPs such as xylanases, peptaibols, swollenin, and cerato-platanins (Druzhinina et al., 2011; Harman et al., 2004a; Shoresh et al., 2010). An early report of induced resistance by Trichoderma spp. is on Trichoderma harzianum T39, which reduced gray mold in bean (De Meyer et al., 1998). Since then T. harzianum T22 (Harman et al., 2004b), T. asperellum T203 (Shoresh et al., 2005), T. harzianum T39 (De Meyer et al., 1998), Trichoderma hamatum 382 (Khan et al., 2004) and Trichoderma koningiopsis Th003 (Moreno et al., 2009) were reported to induce resistance in different plant species against a variety of diseases. The interaction between some Trichoderma strains and plants seems to be associated with ET and JA signaling (Bae et al., 2011; Korolev et al., 2007; Segarra et al., 2009; Shoresh et al., 2005). However, inoculation of roots with Trichoderma did not affect levels of JA and SA (Segarra et al., 2006; Shoresh et al., 2005).

Combining biological control agents can be more effective in the suppression of plant disease, providing enhanced efficacy and reliability from field to field relative to single biocontrol strains (Lutz et al., 2004; Stockwell et al., 2011). Most biocontrol products available on the market are based on combinations of microbial agents. Compatibility and effectiveness of combinations of Trichoderma with other biocontrol organisms is an important issue (Lorito et al., 2010). Enhanced efficacy of mixtures of PGPR and PGPF strains against plant diseases have been reported (Harish et al., 2009; Jetiyanon and Kloepper, 2002; Leeman et al., 1996; Shanmugam et al., 2011), including combinations of Trichoderma and Pseudomonas (Latha et al., 2011; Lutz et al., 2004). However, effectiveness of combined application of Trichoderma and Pseudomonas strains that both elicit induced resistance has as yet not been studied.

In the present study Trichoderma and Pseudomonas isolates from the cucumber rhizosphere were screened for their ability to elicit ISR against Fusarium oxysporum f. sp. radicis cucumerinim (Forc) on cucumber. Possible additive effects of combinations of induced resistance eliciting strains were tested against Forc on cucumber and Botrytis cinerea on wild-type and mutant Arabidopsis.

\section{Materials and methods}

\subsection{Trichoderma and Pseudomonas isolates}

Roots of cucumber plants with adhering rhizosphere soil were sampled from different farms in Iran. Isolation of Trichoderma and Pseudomonas from the root material was carried out by grinding $1 \mathrm{~g}$ of the roots in $10 \mathrm{ml}$ of $10 \mathrm{mM} \mathrm{MgSO}_{4}$ and plating serial dilutions on selective media. Trichoderma was isolated from roots and rhizosphere by serial dilution plating on Trichoderma selective medium as described by Davet and Rouxel (Davet and Rouxel, 2000). Selective medium S1 (Gould et al., 1985), was used for isolation of fluorescent Pseudomonas spp. from the rhizosphere of cucumber. The plates were incubated at $28^{\circ} \mathrm{C}$. After 2 (Pseudomonas) and 4 days (Trichoderma) colonies were selected and for both the bacteria and the fungi pure cultures of 20 strains were obtained. Trichoderma isolate $\operatorname{Tr} 6$ and Pseudomonas Ps14 were studied in the greatest detail. For Ps14 a rifampicin resistant derivative was isolated, according to the method described by Glandorf et al. (1992) to facilitate colonization studies. In experiments with $A$. thaliana, $T$. asperellum $\mathrm{T} 34$ and $P$. fluorescens WCS417 (Segarra et al., 2009), were included. Fusarium oxysporum f.sp. radicis cucumerinum (Forc) strain $\mathrm{F} 42$ was obtained from the agriculture research center of Jiroft, Jiroft, Iran. The Trichoderma strains and Forc F42 were grown on potato dextrose agar (PDA, Difco) and the Pseudomonas strains on Kings medium B (KB, King et al., 1954).

\subsection{Identification of Pseudomonas and Trichoderma}

Pseudomonas isolate Ps14 was identified by sequencing region V6-V8 of the 16S rRNA gene with primers 968f_GC and 1401R (Nubel et al., 1996). Colony PCR was performed as previously described (Sheu et al., 2000), briefly; a reaction master mix was prepared contain $12 \mu \mathrm{MQ}, 2 \mu \mathrm{l}$ Taq buffer containing $\mathrm{MgCl}_{2}\left(\right.$ Invitrogen $^{\circledR}$ ), $2 \mu \mathrm{l}$ of $2 \mathrm{mM}$ dNTPs (Invitrogen ${ }^{\circledR}$ ), $2 \mu \mathrm{l}$ forward and reverse primer (Biolegio10 pmol), and one $\mu$ l Phusion ${ }^{\circledR}$ High-Fidelity DNA Polymerase (Finnzymes). One bacterial colony was added to $19 \mu \mathrm{l}$ of the master mix. PCR was performed using a thermo cycler (Hybaid, Ashford, UK). PCR conditions were $2 \mathrm{~min}$ at $95{ }^{\circ} \mathrm{C}$ followed by 35 cycles of $30 \mathrm{~s}$ at $95^{\circ} \mathrm{C}, 30 \mathrm{~s}$ at $55^{\circ} \mathrm{C}$, and $1 \mathrm{~min}$ at $72{ }^{\circ} \mathrm{C}$, followed by $5 \mathrm{~min}$ at $72^{\circ} \mathrm{C}$. Trichoderma isolate $\operatorname{Tr} 6$ was identified by sequencing of ITS1, 5.8S, and ITS2 rRNA with primer pair ITS1 and ITS4 (5'-TCCGTAGGTGAACCTGCGG-3' and 5'-TCCTCCGCTTAT TGATATGC-3') (Chaverri et al., 2003; Samuels, 2006; White et al., 1990). DNA extraction was carried out by DNasy Qiagene kit according to manufacturer instruction. PCR reaction and PCR condition was used as described for $16 s$ rRNA gene. The PCR product was checked after electrophoresis on a $1.5 \%$ agarose gel in $1 \times$ TAE buffer ( $40 \mathrm{mM}$ Tris-acetate/1 mM EDTA, pH 8). Subsequently the PCR product was purified using Illustra GFX PCR DNA and Gel Band Purification kit (GE, Diegem, Belgium) according to the manufacturer's instructions. The purified PCR products were send to the Macrogen (Amsterdam, the Netherlands) for sequencing. For each amplicon both strands were sequenced using the primer used to generate it.

\subsection{Plant material}

Cucumber seeds (Cucumes sativus L., cv. F1 Barez SF) were obtained from Hamon Agriculture Co. (Tehran, Iran). The seeds were 
surface sterilized for $30 \mathrm{~s}$ in $1 \%$ sodium hypochlorite and rinsed three times with sterile distilled water (Khan et al., 2004). Treated seeds were incubated at $28{ }^{\circ} \mathrm{C}$ for $24 \mathrm{~h}$ between layers of sterile wet filter paper. After $24 \mathrm{~h}$, germinated seeds were planted in $9-\mathrm{cm}$ pots containing a mixture of sand and potting soil that had been autoclaved twice for $20 \mathrm{~min}$ with a $24 \mathrm{~h}$ interval. Plants were cultivated in a growth chamber with a $16 \mathrm{~h}$ day $\left(24^{\circ} \mathrm{C}\right)$ and $8 \mathrm{~h}$ night $\left(20^{\circ} \mathrm{C}\right)$ cycle at $70 \%$ relative humidity. The seedlings were watered two times a week, alternating half strength Hoagland and tap water (Hoagland and Arnon, 1950). For split root experiment the germinated seeds were planted in $60-\mathrm{ml}$ pots filled with two times sterilized vermiculite. Seeds of wild-type $A$. thaliana Col-0 and mutants ein2-1 (Guzmán and Ecker, 1990), myb72-1 (Van der Ent et al., 2008), and sid2-1 (Nawrath and Métraux, 1999), were sown in autoclaved river sand, and incubated at $100 \%$ relative humidity and $21^{\circ} \mathrm{C}$, and $8 \mathrm{~h}$ photoperiod. Twoweek-old seedlings were transplanted into $60-\mathrm{ml}$ pots containing a potting soil-sand mixture $(12: 5 \mathrm{~V} / \mathrm{V})$ that had been autoclaved twice with a $24 \mathrm{~h}$ interval. Plants were grown in a growth chamber with $70 \%$ relative humidity, at $21^{\circ} \mathrm{C}$, and an $8 \mathrm{~h}$ photoperiod, as described previously (Pieterse et al., 1996).

\subsection{Microbial inoculum preparation}

Inoculum of the Trichoderma isolates and Forc strain F42 were prepared by culturing on potato dextrose agar (PDA) for 7 (Trichoderma) and 14 (Forc) days at $28^{\circ} \mathrm{C}$. Conidia were collected from the agar plates, filtered through glass wool and suspended in $10 \mathrm{mM}$ $\mathrm{MgSO}_{4}$. The inoculum concentration was adjusted to a final density after counts in a haemocytometer. For stem inoculation, spore suspensions of Forc were prepared in half strength potato dextrose broth (PDB) at a density of $10^{7}$ spores $/ \mathrm{ml}$. For soil drench, spore suspensions were prepared in $10 \mathrm{mM} \mathrm{MgSO}_{4}$ and added to the soil to a final inoculum density of $10^{5} \mathrm{cfu}$ per $\mathrm{g}$ soil. $\mathrm{B}$. cinerea was cultured on half strength PDA for 2 weeks at $21^{\circ} \mathrm{C}$. Spore suspensions were prepared in half strength PDB $\left(10^{5}\right.$ spores $\left./ \mathrm{ml}\right)$ and incubated for $2 \mathrm{~h}$ at room temperature prior to inoculation.

Suspensions of the Pseudomonas strains were obtained from overnight cultures incubated at $28^{\circ} \mathrm{C}$ on $\mathrm{KB}$ agar. Bacterial cells were scraped of the plates in $10 \mathrm{mM} \mathrm{MgSO}_{4}$, centrifuged at $5000 \mathrm{rpm}$ for $10 \mathrm{~min}$, and resuspended in $10 \mathrm{mM} \mathrm{MgSO}_{4}$. The density of the suspension was set at $10^{9}$ colony forming units $(\mathrm{cfu}) / \mathrm{ml}$ by measuring the OD at $660 \mathrm{~nm}$ spectrophotometrically.

\subsection{Inoculation of plants}

Soil was inoculated with Trichoderma $\left(10^{3}\right.$ spores/g) or Pseudomonas $\left(10^{3} \mathrm{cfu} / \mathrm{g}\right)$ by mixing the suspension into the soil after which seedlings were transplanted into the treated soil. Alternatively, seedlings were transplanted into the soil and three days before challenge inoculation with the pathogen, Trichoderma $\left(10^{5}\right.$ spores/g of soil) or Pseudomonas $\left(10^{7} \mathrm{cfu} / \mathrm{g}\right.$ of soil) were applied as a soil drench.

Cucumber plants were inoculated with Forc F42 in different ways. In the split root experiments the soil was drenched three day after introduction of the biocontrol agents with Forc F42 in a final density of $10^{5}$ spores per gram of soil (Liu et al., 1995). For stem inoculation, a $15 \mu$ d droplet of a suspension $\left(10^{7}\right.$ spores $/ \mathrm{ml}$ in half strength $\mathrm{PDB}$ ) was placed on the stem of seedlings at the two true leaves stage. Using a scalpel blade an incision was made in the stem through the $15 \mu \mathrm{l}$ droplet resulting in rapid uptake of the conidia into the xylem (Duijff et al., 1993). For inoculation of Arabidopsis with $B$. cinerea, $5 \mu \mathrm{l}$ droplets of a pregerminated spore suspension $\left(10^{5}\right.$ spores $/ \mathrm{ml}$ in half strength $\left.\mathrm{PDB}\right)$ were placed on four to six leaves of each plant (24 plants for each treatment). Inoc- ulated plants were grown at $100 \%$ relative humidity and disease symptoms were scored after three days.

\subsection{Screening for induced resistance in cucumber}

Two weeks old seedlings, grown on sterilized vermiculite, were carefully removed from the substrate and the root system was gently divided in two equal parts. Subsequently these plants were transplanted into two pots (filled with an autoclaved mix of potting soil and sand) such that the two separate parts of the root system were in separate pots (Khan et al., 2004; Liu et al., 1995; Zang et al., 1996). Trichoderma and Pseudomonas isolates were screened for activity against Forc in this split root system. Three days after transplanting, one part of the root system was inoculated with the biocontrol agent and after another three days the other part was inoculated with the pathogen. The plants were kept at $24^{\circ} \mathrm{C}$, $70 \%$ relative humidity and a $16 \mathrm{~h}$ photoperiod and they were watered twice a week with sterilized tap water. After four weeks disease symptoms were scored. Disease was scored in 5 classes (0-4) with $0=$ healthy, $1=$ mild stem rot, $2=$ spreading stem rot (less than $2 \mathrm{~cm}$ ), 3 = severe spreading, and 4 =dead. The disease incidence index was calculated by transforming the classes to \% as $0=0 \%, 1=25 \%, 2=50 \%, 3=75 \%$, and $4=100 \%$.

\subsection{Control of Fusarium in cucumber by the combination of Trichoderma and Pseudomonas}

T. harzianum $\operatorname{Tr} 6$ and Pseudomonas sp. Ps14 were mixed through sterilized soil to a final inoculum density of $10^{3}$ spores or cfu per $g$ of soil. Four treatments were compared, control, T. harzianum Tr6, Pseudomonas sp. Ps14, and the combination of $\operatorname{Tr} 6$ and Ps14, with 15 replicates for each treatment. Three weeks old seedlings were inoculated with Forc using stem inoculation (see inoculation of plants). After 2-4 weeks disease incidence was scored. Spatial separation of the pathogen and the antagonists was tested at the end of the bioassay by culturing stem and root samples on selective media.

\subsection{A. thaliana - Botrytis cinerea bioassays}

P. fluorescens WCS417r and T. asperellum T34, both well studied for eliciting induced resistance in A. thaliana (Pieterse et al., 1996; Segarra et al., 2009), were studied for their combined effects against $B$. cinerea. The involvement of MYB72 was investigated using A. thaliana mutant myb72-1 (Van der Ent et al., 2008). The abilities of strains Tr6, Ps14 and their combination to elicit ISR against $B$. cinerea were studied on $A$. thaliana Col-0, and mutants myb72-1, sid2-1 (Nawrath and Métraux, 1999) and ein2-1 (Guzmán and Ecker, 1990) to study the involvement of MYB72, SA, and ET signaling, respectively. The percentage of spreading lesions was scored three days after inoculation with the pathogen.

\subsection{Colonization of cucumber and Arabidopsis rhizosphere by $\operatorname{Tr} 6$ and Ps14}

In bioassays with cucumber and Arabidopsis, population densities of the introduced beneficial microorganisms were studied both when they were singly inoculated and for the combined inoculation. Rhizosphere samples were obtained from plants at four weeks after inoculation of the roots. $0.5 \mathrm{~g}$ of the sample was suspended in $5 \mathrm{ml}$ of sterile $0.01 \mathrm{M} \mathrm{MgSO}_{4}$ and shaken with $0.5 \mathrm{~g}$ glass beads (0.6-0.8 mm diameter) for $1 \mathrm{~min}$ on a vortex at maximum speed. Numbers of colony forming units (cfu) of Pseudomonas sp. Ps14 were determined by dilution plating on KB agar supplemented with $40 \mathrm{mg} / \mathrm{l}$ ampicillin, $13 \mathrm{mg} / \mathrm{l}$ chloramphenicol, $100 \mathrm{mg} / \mathrm{l}$ natamycin (Delvocid, DSM, Delft, NL) and $150 \mathrm{mg} / \mathrm{l}$ rifampicin 
(Doornbos et al., 2010). Population densities of Tr6 were determined by dilution plating on Trichoderma selective medium as described by Davet and Rouxel (Davet and Rouxel, 2000). In the control treatments of the different experiments no counts were observed for Trichoderma showing that indigenous populations were below detection.

\subsection{Gene expression in cucumber and Arabidopsis}

To evaluate expression of defense related genes in the different experiments samples of cucumber stems and Arabidopsis leaves were flash frozen in liquid nitrogen and stored at $-80{ }^{\circ} \mathrm{C}$ until required. RNA was extracted individually from the samples of three replicates for each treatment. Samples were ground with mortar and pestle in liquid nitrogen and total RNA was extracted with RNeasy Qiagen kit according to the instructions of the manufacturer. Extracted RNA was treated with DNase (Ambion). Before cDNA synthesis RNA samples were screened for genomic contamination by PCR with primer pair (5'-GTCAAAATACTGGGAAGATC-3' and $5^{\prime}$-TTTGAGGTAGGAAGTGTAGT- $3^{\prime}$ ) to amplify an intron sequence of a gene encoding the HSP70 gene for cucumber samples (Wan et al., 2010), and with primer pair EIL2 (5'-ATTATCACCACCCTTTCGCAGT-3' and 5'-CCGTATGCGAATCAGAACACAT-3') for EIN2-like gene for Arabidopsis samples (Pozo et al., 2008). Subsequently, DNA-free total RNA was converted into cDNA using oligo-dT primers (Invitrogen, Breda, the Netherlands), $10 \mathrm{mM}$ dNTPs, and Revert Aid H minus Reverse Transcriptase (Fermentas EP0452/EP0451) according to the manufacturer's instructions.

\subsection{1. $q P C R$}

The following primers were used: $E F \quad 1-\alpha$, forward $5^{\prime}$ CTGTGCTGTCCTCATTATTG-3' and reverse 5'-AGGGTGAAAGCA AGAAGAGC-3'; CHIT1, forward 5'-TGGTCACTGCAACCCTGACA-3'and reverse 5'-AGTGGCCTGGAATCCGACT-3'; CACS, forward 5'TGGGAAGATTCTTATGAAGTGC-3' and reverse 5'-CTCGTCAAATTTA CACATTGGT-3'; $\beta$-1,3-Glucanase, forward 5'-TCAATTATCAAAACTT GTTCGATGC-3' and reverse 5'-AACCGGTCTCGGATACAACAAC-3'; PAL1, forward 5'-ATGGAGGCAACTTCCAAGGA-3' and reverse 5'CCATGGCAATCTCAGCACCT-3'; PR1, forward 5'-TGCTCAACAA TATGCGAACC- $3^{\prime}$ and reverse 5'-TCATCCACCCACAACTGAAC-3'; LOX1, forward, 5'-CTCTTGGGTGGTGGTGTTTC-3' and reverse $5^{\prime}$ TGGTGGGATTGAAGTTAGCC-3' (Migocka and Papierniak, 2011; Shoresh et al., 2005; Wan et al., 2010). Primers for LOX1 and PR1 were designed using primer3 (http://frodo.wi.mit.edu/primer3/input.htm). PCR products for primers were between 100-200 bp with $\mathrm{TM}=60^{\circ} \mathrm{C}$. Primers for Arabidopsis genes were PR1, Forward 5'-CTCGGAGCTACGCAGAACAACT-3' and reverse 5'TTCTCGCTAACCCACATGTTCA-3'; PDF1.2, forward, 5'-TTTGCTG CTTTCGACGCAC-3' and reverse 5'-CGCAAACCCCTGACCATG-3'; and $b$-Actin2, forward 5'-AGTGGTCGTACAACCGGTATTGT-3' and reverse 5'-GATGGCATGAGGAAGAGAGAAAC-3'.

PCR reactions were carried out in 96 -well plates $(20 \mu \mathrm{l}$ per well). The reaction mixture contained $2 \mu \mathrm{l}$ of diluted $\mathrm{CDNA}, 10 \mu \mathrm{l}$ SYBR $^{\circledR}$ Green mix (AB Applied Biosystems, Foster, CA) and $8 \mu \mathrm{l}$ primers mix (Biolegio $1 \mathrm{pmol}$ ). Efficiency of primers was calculated by dilution method. Quantitative real time PCR was performed using the GeneAmp 7900HT Sequence Detection System (AB Applied Biosystems) at $95^{\circ} \mathrm{C}$ for $10 \mathrm{~min}$ followed by 40 cycles at $95{ }^{\circ} \mathrm{C}$ for $15 \mathrm{~s}$ and at $60^{\circ} \mathrm{C}$ for $1 \mathrm{~min}$. Genes EF $1-\alpha$ and CACS were used as reference genes in the cucumber experiments. In Arabidopsis experiments the b-Actin2 gene was used as reference gene. Relative expression of genes of interest was calculated according to Pfaffi (Pfaffl, 2001).

\subsection{Statistics}

Statistical analysis was performed with SPSS 16.0. Results from the bioassays for control of Fusarium stem and root rot in cucumber were analyzed after Box-Cox transformation, using ANOVA followed by Duncan post hoc test. Gene expression levels were analyzed by one way ANOVA followed by the Duncan post hoc test. The colonization data were log transformed and analyzed by ANOVA followed by Duncan post hoc. The A. thaliana - B. cinerea bioassays were analyzed using non parametric logistic regression analysis.

\section{Results}

\subsection{Isolation of Trichoderma and Pseudomonas and screening for induced resistance}

Twenty isolates of Trichoderma and twenty isolates of Pseudomonas were isolated from cucumber rhizosphere on selective media. To select isolates that effectively elicit induced resistance in cucumber against Forc F42, they were screened in a split root system. Pseudomonas isolates Ps9, Ps14, Ps12, and Ps6 and Trichoderma isolates $\operatorname{Tr} 6$ and $\operatorname{Tr} 9$ significantly reduced disease severity in these experiments (Fig. $1 \mathrm{~A}$ and $\mathrm{B}$ ). Both in vitro (growth on plates) and in vivo (colonization of the cucumber rhizosphere) no significant antagonistic interactions between the Pseudomonas and Trichoderma isolates were detected (data not shown). Based on their performance in the ISR bioassay, Ps14 and Tr6 were selected for further experiments. A homology search in GenBank DNA sequence database, using BLASTn, the V6-V8 region sequence of the 16S rRNA gene of Ps14 revealed 99\% and 98\% homology to Pseudomonas sp. (accession number AB714640 and AY365082). Sequencing of ITS1, 5.8S, ITS2 of Trichoderma isolate Tr6 and a homology search on TrichOKEY 2 (http://isth.info/tools/molkey/index.php) and BLASTn showed 99\% homology with T. harzianum (accession numbers JN942884 and HQ608137). Sequences were deposited in Genbank ${ }^{57}$ with accession numbers JX411632 for Ps14 and JX411633 for Tr6.

\subsection{Combined effect of Trichoderma and Pseudomonas in control of Fusarium stem and root rot of cucumber}

To investigate the effect of combined treatment with Ps14 and $\operatorname{Tr} 6$ on the level of ISR, cucumber plants were inoculated with different densities of both strains and the level of resistance against Forc was evaluated. Starting densities of $10^{3} \mathrm{cfu}$ per $\mathrm{g}$ of soil for both Tr6 and Ps14 controlled disease more effectively than higher densities of $10^{5}$ and $10^{7} \mathrm{cfu}$ per $\mathrm{g}$ (data not shown). As shown in Fig. 2, both $\operatorname{Tr} 6$ and Ps14 induced resistance against Forc F42, but the combination of $\operatorname{Tr} 6$ and Ps14 suppressed the disease significantly better compared to the individual treatments.

\subsection{Expression of defense-related genes in cucumber before and after challenge inoculation with Fusarium}

To investigate effects of $\operatorname{Tr} 6$ and Ps 14 on expression of defense related genes in cucumber, we studied expression of CHIT1, $\beta$-1,3Glucanase, and PAL1, encoding Chitinase, glucanase, and phenylalanine ammonia-lyase, respectively. Expression levels of these genes were determined in a 0 to $96 \mathrm{~h}$ time series after challenge inoculation with Fusarium. In control treated plants, Forc inoculation resulted in a gradual increase in the expression of $\beta-1,3-$ Glucanase. In plants pretreated with either Ps14 or Tr6, this augmented expression was significantly increased, indicating that $\beta-1,3-$ Glucanase expression is primed by the treatment with the 
A

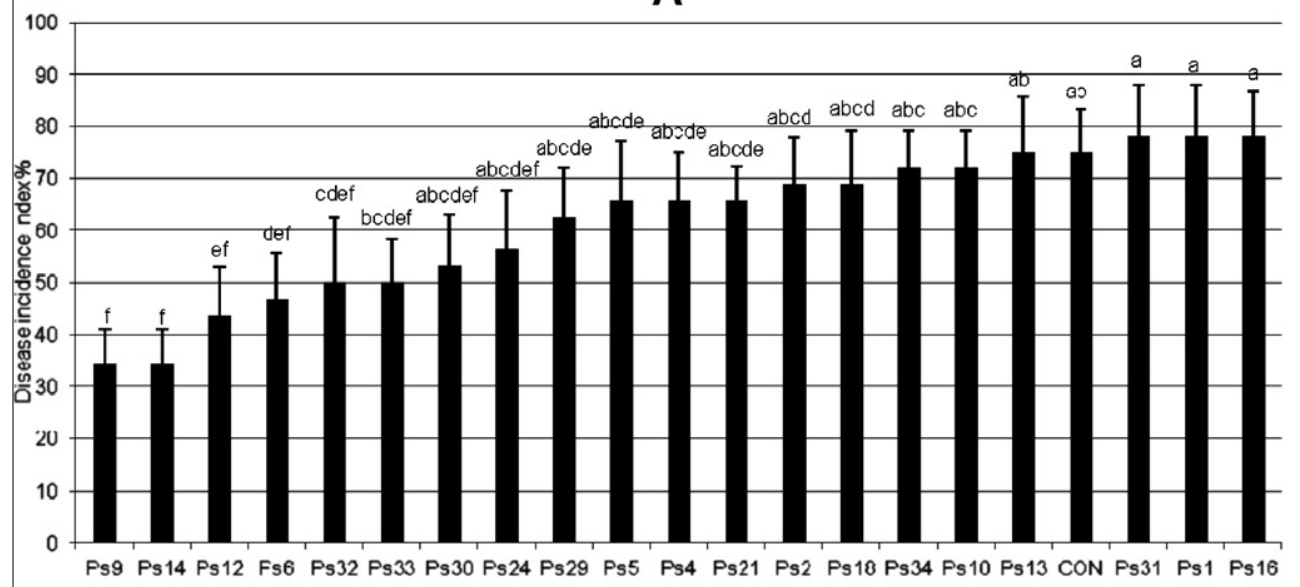

B

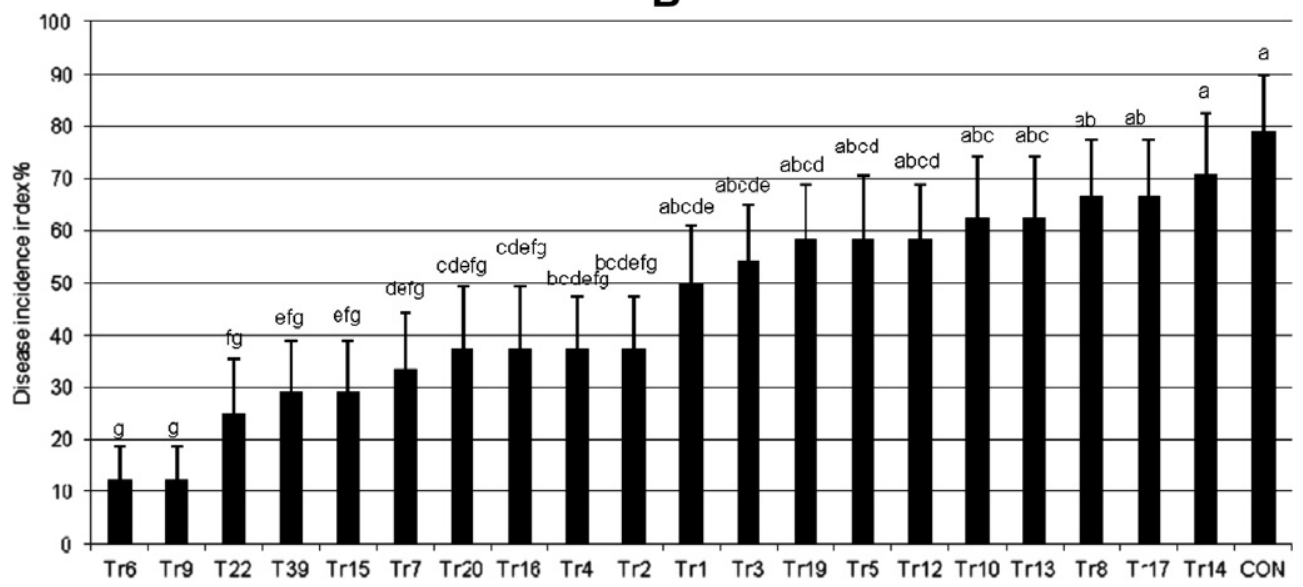

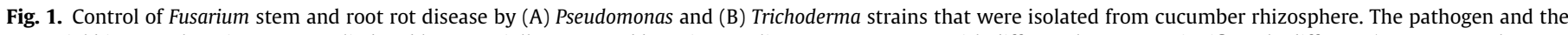

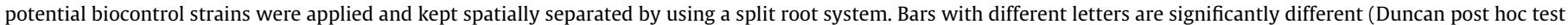
$P<0.05)$.

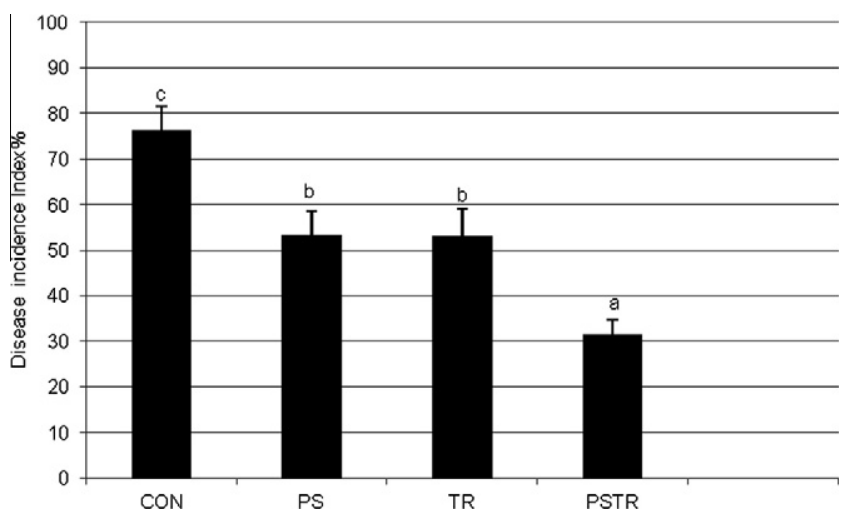

Fig. 2. Control of Fusarium stem and root rot disease by individual and combined application of T. harzianum Tr6 (TR) and Pseudomonas sp. Ps14 (PS). The biocontrol agents and the pathogen were applied and maintained spatially separated by inoculating the biocontrol strains on the roots and inoculating the pathogen into the stem. Bars with different letters are significantly different (Duncan post hoc test, $P<0.05$ )

biological control strains. Interestingly, the primed expression pattern of $\beta-1,3-$ Glucanase was significantly more pronounced in the combination treatment (Fig. 3), which parallels the enhanced level of protection observed in these plants (Fig. 2). For the relative expression of CHIT1 at the different time points after inoculation with Forc a similar result was observed (Fig. 3). Also for PAL1 primed expression was observed in the Ps14, Tr6 and the combination treatments, but the combination treatment did not result in enhanced up-regulation (Fig. 3). Whereas expression of $P R-1$ was not affected by the Ps14 treatment, it was primed by Tr6, and in the combination treatment this was significantly more pronounced (Fig. 3). Finally expression of LOX1 was primed by all treatments but there was no enhanced effect of the combination treatment (Fig. 3). Thus suppression of Fusarium in cucumber by the biocontrol agents is accompanied by primed expression of several defense related genes and augmented disease suppression by the combination of Ps14 and Tr6 is accompanied by enhanced priming for some of these genes.

\subsection{Does combined application of Pseudomonas and Trichoderma lead to enhanced induced resistance in Arabidopsis?}

To study if the combined application of Trichoderma and Pseudomonas also leads to more effective induced resistance in Arabidopsis we studied two combinations for their abilities to elicit ISR against B. cinerea. First of all the combination of Ps14 and Tr6 was studied. P. fluorescens WCS417 and T. asperellum T34 were used as a control as it was previously demonstrated that they elicit ISR in Arabidopsis and that for both micro-organisms this is dependent on the A. thaliana transcription factor MYB72 (Segarra et al., 2009; Van der Ent et al., 2008). The combination of WCS417 and 
$\beta-1,3-G l u c a n a s e$

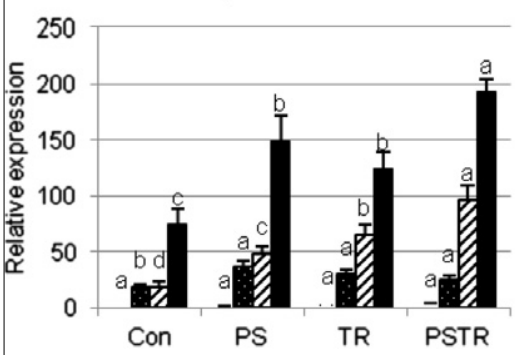

PAL1

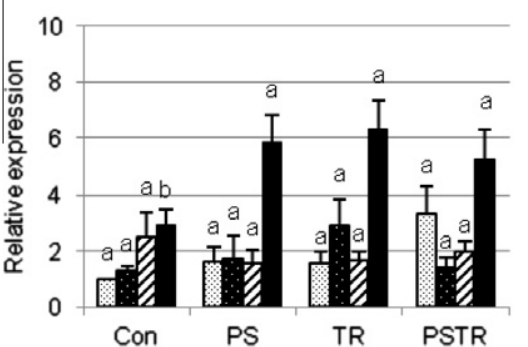

CHIT1

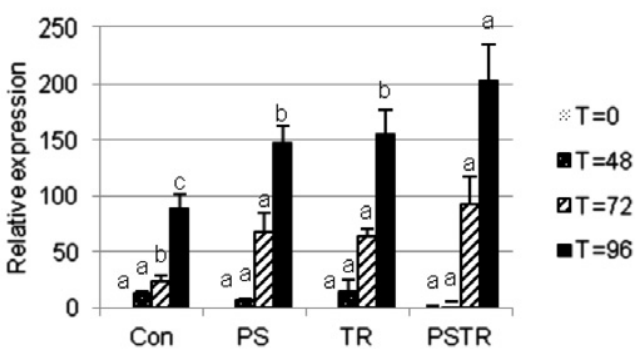

PR1

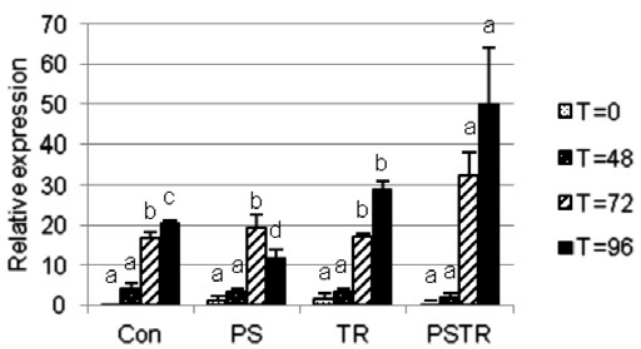

LOX1

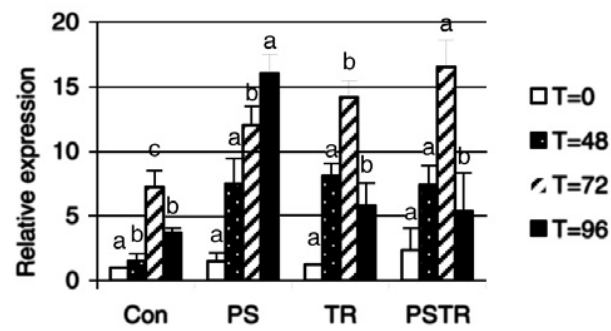

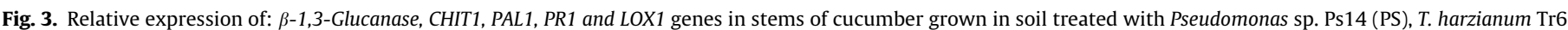

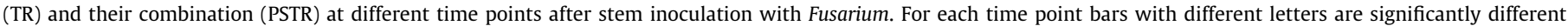
(Duncan post hoc test, $P<0.05$ ).

T34 did not lead to improved control of $B$. cinerea as compared to the single treatments (Fig. 4) and the biocontrol agents and their combination were not effective in the myb72 mutant (Fig. 4), confirming earlier observations (Segarra et al., 2009). Trichoderma Tr6, Pseudomonas Ps14, and their combination significantly reduced the percentage disease caused by $B$. cinerea in Arabidopsis (Fig. 5). However, in contrast to their effects in cucumber the combination of the two biocontrol agents did not result in improved disease control. ISR elicited by Tr6 and Ps14 was not dependent on salicylic acid as both micro-organisms also reduced disease in the sid2 mutant (Fig. 5). In the myb72 mutant none of the treatments reduced disease (Fig. 5) suggesting that also for these micro-organisms ISR is dependent on MYB72. We studied the expression of PDF1.2 and PR1 in Arabidopsis both before and $48 \mathrm{~h}$ after infection with $B$. cinerea. At $48 \mathrm{~h}$ after infection expression of PDF1.2 was primed in the treatments with Ps14 and Tr6, and no enhanced effect was observed for the combination treatment (Fig. 6). Expression levels of PR1 were not affected by the treatments with Trichoderma, Pseudomonas and their combination (Fig. 6).

\section{Col-0}

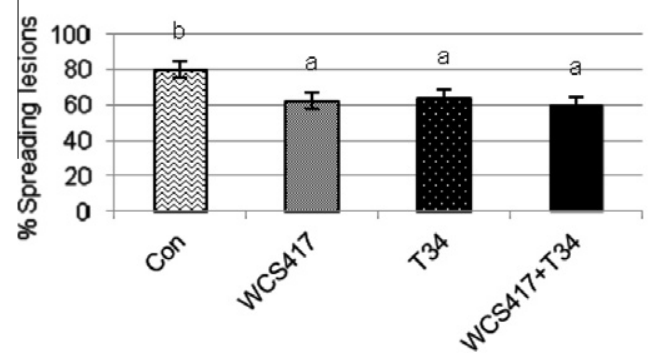

myb72

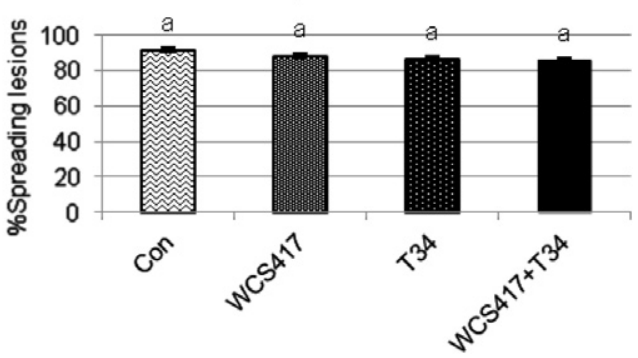

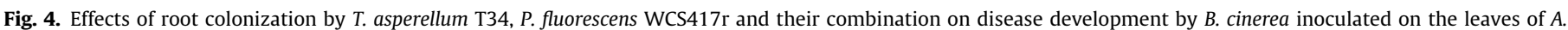

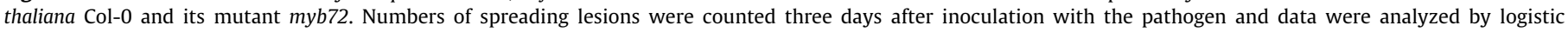
regression. Bars with different letters are significantly different $(P<0.05)$. 
Col-0
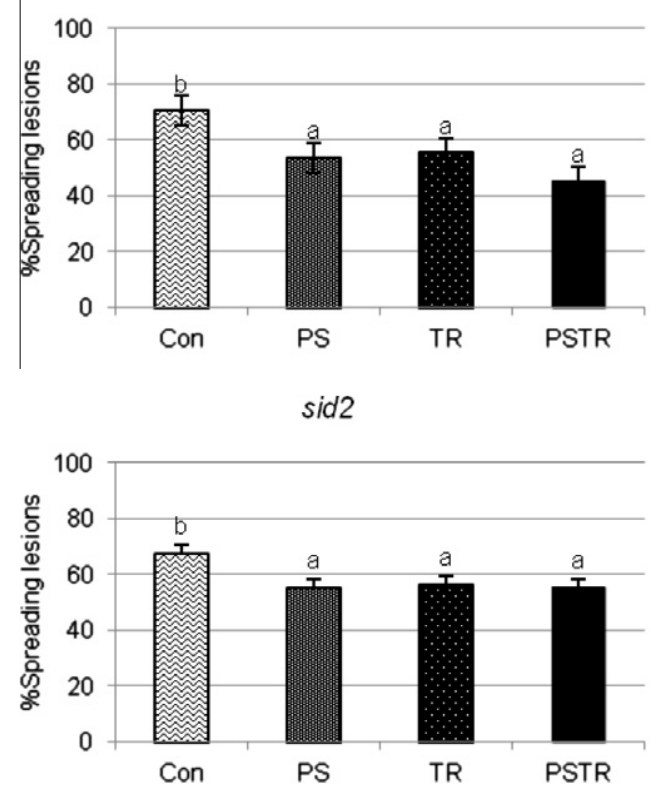

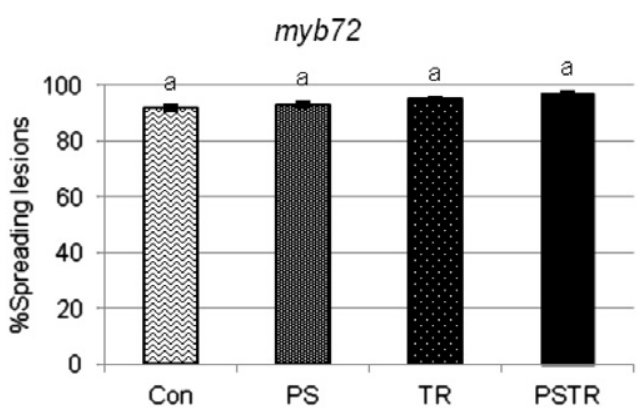

ein2

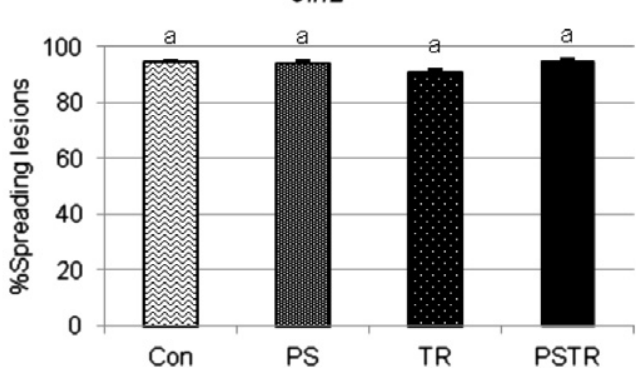

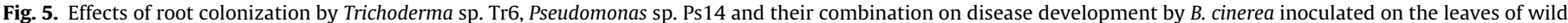

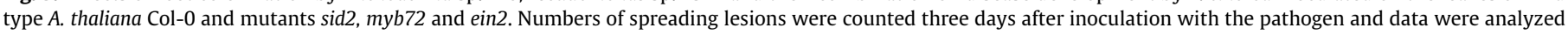
by logistic regression. Bars with different letters are significantly different $(P<0.05)$.
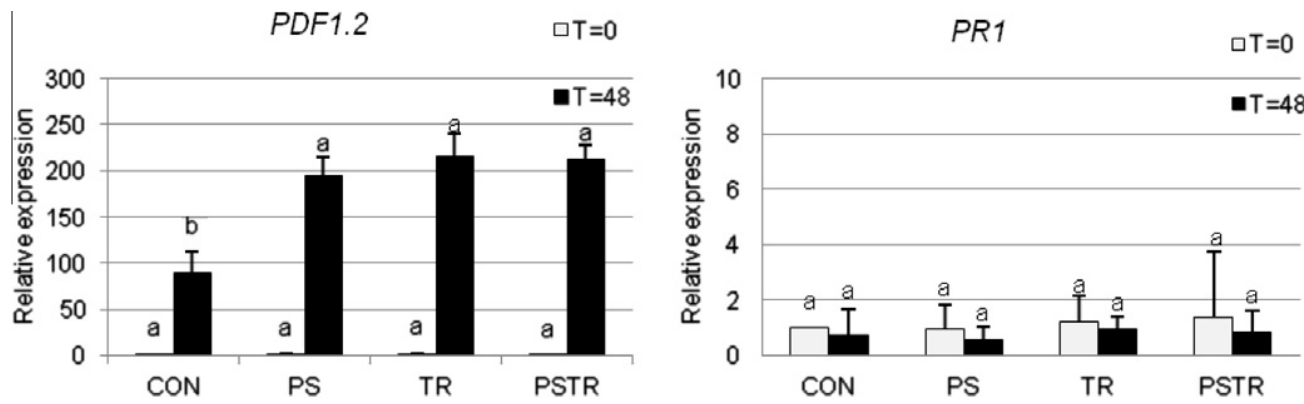

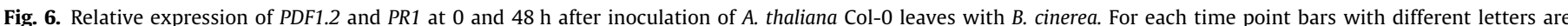
significantly different (Duncan post hoc test, $P<0.05$ ).

\subsection{Compatibility between Trichoderma Tr6 and Pseudomonas Ps14 in the rhizosphere}

Root colonization by Trichoderma Tr6 and Pseudomonas Ps14 was studied in both cucumber and Arabidopsis. When introduced alone, the Pseudomonas strain reached population densities between $10^{6}$ and $10^{7} \mathrm{cfu}$ per gram of root on both plant species. In the combined treatment population densities of Ps14 were not influenced by the presence of Trichoderma (Fig. 7A and C). For Trichoderma $\operatorname{Tr} 6$ similar results were obtained. The fungal strain reached population densities around $10^{4} \mathrm{cfu}$ per gram of root on both plant species, and these densities were not influenced by the presence of Pseudomonas Ps14 in the combination treatment (Fig. 7B and D). Thus it appears that these two biological control agents are compatible in the rhizospheres of cucumber and Arabidopsis.

\section{Discussion}

Combinations of biocontrol agents can result in more effective and robust control of plant diseases (De Boer et al., 2003; Leeman et al., 1996). We studied possible enhanced effectiveness of combinations of Trichoderma and Pseudomonas in ISR in cucumber and Arabidopsis. Using a split root system in cucumber it was demonstrated that Trichoderma isolates $\operatorname{Tr} 6$ and $\operatorname{Tr} 9$ and Pseudomonas isolates Ps6, Ps9, Ps12, and Ps14, all isolated from cucumber rhizosphere, can elicit ISR in cucumber against Forc F42. Isolates $\operatorname{Tr} 6$ and Ps14 most effectively reduced disease, and these strains were used in the rest of this study. The strains were identified as T. harzianum (Tr6) and Pseudomonas sp. (Ps14), based respectively on ITS and $16 \mathrm{~S}$ sequences.

Enhanced efficacy of biocontrol of plant diseases by combinations of Trichoderma and Pseudomonas have been reported (Latha et al., 2011; Lutz et al., 2004), but combined effects of strains that induce resistance have as such not been studied. ISR by the combination of Ps14 and Tr6 provided significantly better protection of cucumber against Forc F42 than individual application of the biocontrol agents. Trichoderma and Pseudomonas could not be detected on the non-inoculated plant parts, this is indicative of persistent spatial separation of the biocontrol agents and the pathogen in these bioassays. In addition, Tr6 and Ps14 did not show in vitro antagonistic activity against Forc F42 (data not shown). Thus the control of disease by Tr6, Ps14 and their combination 
A

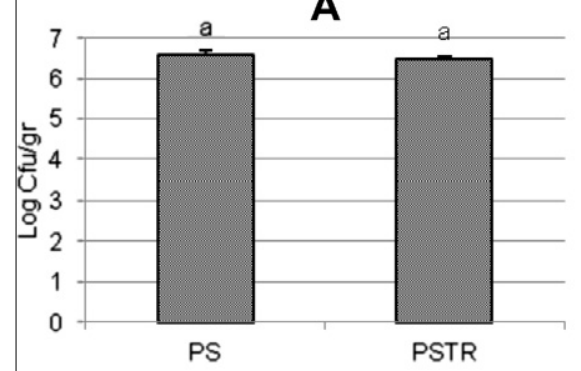

C

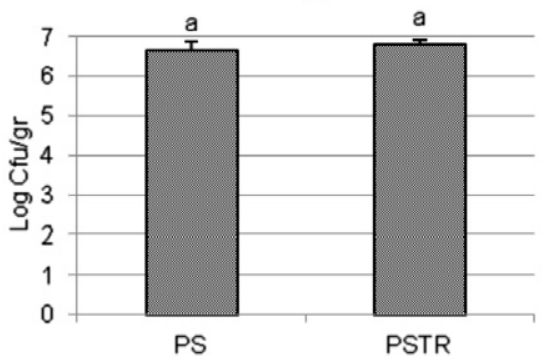

B

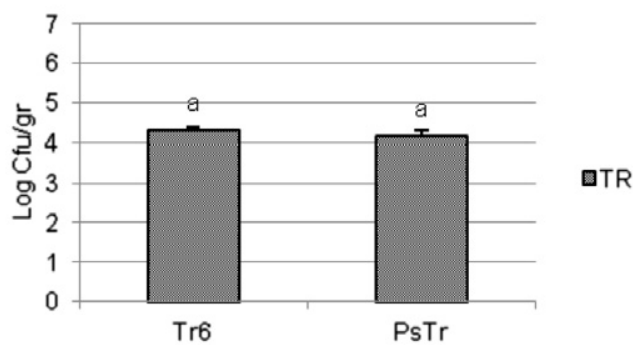

D

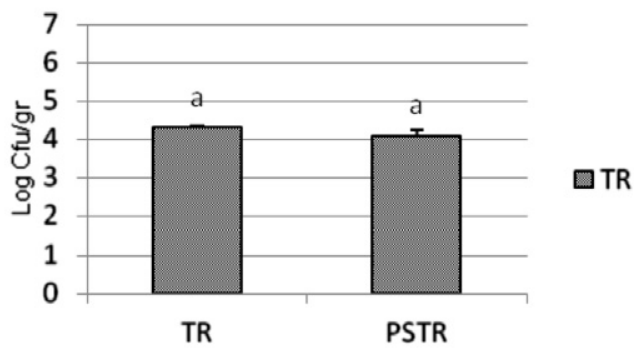

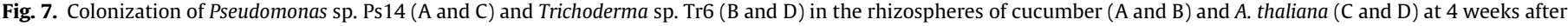
introduction of these microorganisms in the soil. For each time point bars with different letters are significantly different $(D u n c a n$ post hoc test, $P<0.05)$.

must be plant mediated. In A. thaliana simultaneous activation of salicylate and jasmonate dependent defense pathways lead to enhanced induced resistance (Van Wees et al., 2000). Thus the enhanced effectiveness of Tr6 and Ps14 in cucumber suggests that Trichoderma and Pseudomonas trigger different signal transduction pathways. Induced resistance for many strains of fluorescent Pseudomonas spp. is SA-independent and JA and ET signaling dependent (Bakker et al., 2007; Pieterse et al., 2003; Van Loon et al., 1998). Some studies reported that ISR by Trichoderma agents involves JA and ET signaling (Bae et al., 2011; Djonovic et al., 2007; Korolev et al., 2007; Moreno et al., 2009; Segarra et al., 2009; Shoresh et al., 2005; Viterbo et al., 2007), whereas in other cases it seemed SA-dependent (Alfano et al., 2007; Shoresh and Harman, 2008). Moreover activation of both the SA and JA pathway by some strains of Trichoderma has been reported (Harman, 2011; Salas-Marina et al., 2011; Segarra et al., 2007; Yoshioka et al., 2012).

Colonization of the rhizosphere by PGPRs and PGPFs leads to primed defense reactions such as up regulation of genes encoding PR proteins and genes which are involved in defense signaling pathways after pathogen challenge (Conrath et al., 2006; Conrath et al., 2002; De Vleesschauwer and Höfte, 2009; Pozo et al., 2008; Shoresh et al., 2005; Van der Ent et al., 2009a; Van Wees et al., 1999). After challenge inoculation with Forc F42, primed expression of the CHIT1, $\beta-1,3-$ Glucanase, PAL1, PR1 and LOX1 in stems of cucumber plants treated with Ps14, Tr6, or their combination was observed. These results are consistent with Shoresh et al. (2005) who reported primed gene expression in cucumber by $T$. asperellum T203 against Pseudomonas syringae pv. Lachrymans and with reports on priming of defense-related genes by $P$. fluorescens WCS417 in A. thaliana (Hase et al., 2003; Pieterse et al., 2000; Van Wees et al., 1999).

Arabidopsis is a model plant for induced resistance and different mutants in induced resistance pathways are available. We used $A$. thaliana mutants sid2 and myb72 to study respectively the involvement of SA signaling and of the transcription factor MYB72, in ISR by Trichoderma, Pseudomonas and their combination. Transcription factor MYB72 is required in the roots during early signaling steps of $P$. fluorescens WCS417 $\mathrm{r}$ and $T$. asperellum T34-mediated ISR (Segarra et al., 2009; Van der Ent et al., 2008). Indeed bioassays withWCS417r, T34 and their combination confirmed that MYB72 is essential for the onset of ISR, in this case against $B$. cinerea. As expected the combination of these two well-studied biocontrol agents did not result in enhanced disease control, since they appear to activate the same signal transduction pathway. Real time qPCR showed up regulation of PDF1.2. Based on the observation that the combination of Ps14 and Tr6 shows enhanced effectiveness in a cucumber ISR bioassay we expected similar effects in Arabidopsis. However, whereas both biocontrol agents did elicit ISR in Arabidopsis, their combination was not more effective in disease suppression. In accordance to this ISR by both Ps14 and $\operatorname{Tr} 6$ depended on MYB72 but it was independent of SA signaling. Following this line of reasoning the enhanced disease suppression by the combination of Ps14 and $\operatorname{Tr} 6$ in cucumber is most likely due to activation of different signaling pathways by these micro-organisms. Developing mutants in cucumber affected in specific defense signaling pathways is necessary to explore this phenomenon more in depth.

\section{Acknowledgments}

This project was financially supported by University of Jiroft.

\section{References}

Alfano, G., Ivey, M.L., Cakir, C., Bos, J.I., Miller, S.A., Madden, L.V., Kamoun, S., Hoitink, H.A., 2007. Systemic modulation of gene expression in tomato by Trichoderma hamatum 382. Phytopathology 97, 429-437.

Bae, H., Roberts, D.P., Lim, H.S., Strem, M.D., Park, S.C., Ryu, C.M., Melnick, R.L. Bailey, B.A., 2011. Endophytic Trichoderma isolates from tropical environments delay disease onset and induce resistance against Phytophthora capsici in hot pepper using multiple mechanisms. Molecular Plant-Microbe Interactions 24, 336-351.

Bakker, P.A.H.M., Pieterse, C.M.J., Van Loon, L.C., 2007. Induced systemic resistance by fluorescent Pseudomonas spp. Phytopathology 97, 239-243.

Bent, E., 2006. Induced systemic resistance medidated by plant growth-promoting rhizobacteria (PGPR) and fungi (PGPF). In: Tuzun, S., Bent, E. (Eds.), Multigenic and Induced Systemic Resistance in Plants. Springer, US, pp. 225-258.

Berendsen, R.L., Pieterse, C.M., Bakker, P.A.H.M., 2012. The rhizosphere microbiome and plant health. Trends in Plant Science 17, 478-486.

Chaverri, P., Castlebury, L.A., Samuels, G.J., Geiser, D.M., 2003. Multilocus phylogenetic structure within the Trichoderma harzianum/Hypocrea lixii complex. Molecular Phylogenetics and Evolution 27, 302-313.

Conrath, U., Pieterse, C.M.J., Mauch-Mani, B., 2002. Priming in plant-pathogen interactions. Trends in Plant Science 7, 210-216. 
Conrath, U., Beckers, G.J., Flors, V., Garcia-Agustin, P., Jakab, G., Mauch, F., Newman, M.A., Pieterse, C.M.J., Poinssot, B., Pozo, M.J., Pugin, A., Schaffrath, U., Ton, J., Wendehenne, D., Zimmerli, L., Mauch-Mani, B., 2006. Priming: getting ready for battle. Molecular Plant-Microbe Interactions 19, 1062-1071.

Davet, P., Rouxel, F., 2000. Detection and isolation of soil fungi. In: Thanikaimoni, K. (Ed.), Soil Fungi-Laboratory Manuals. Science Publishers, USA, p. 188.

De Boer, M., Bom, P., Kindt, F., Keurentjes, J.J.B., Van der Sluis, I., Van Loon, L.C., Bakker, P.A.H.M., 2003. Control of Fusarium wilt of radish by combining Pseudomonas putida strains that have different disease-suppressive mechanisms. Phytopathology 93, 626-632.

De Meyer, G., Bigirimana, J., Elad, Y., Höfte, M., 1998. Induced systemic resistance in Trichoderma harzianum T39 biocontrol of Botrytis cinerea. European Journal of Plant Pathology 104, 279-286.

De Vleesschauwer, D., Höfte, M., 2009. Rhizobacteria-induced systemic resistance. In: Van Loon, L.C. (Ed.), Advances in Botanical Research. Academic Press, pp. 223-281.

Djonovic, S., Vargas, W.A., Kolomiets, M.V., Horndeski, M., Wiest, A., Kenerley, C.M., 2007. A proteinaceous elicitor Sm1 from the beneficial fungus Trichoderma virens is required for induced systemic resistance in maize. Plant Physiology $145,875-889$.

Doornbos, R.F., Geraats, B.P.J., Kuramae, E.E., Van Loon, L.C., Bakker, P.A.H.M., 2010. Effects of jasmonic acid, ethylene, and salicylic acid signaling on the rhizosphere bacterial community of Arabidopsis thaliana. Molecular PlantMicrobe Interactions 24, 395-407.

Druzhinina, I.S., Seidl-Seiboth, V., Herrera-Estrella, A., Horwitz, B.A., Kenerley, C.M., Monte, E., Mukherjee, P.K., Zeilinger, S., Grigoriev, I.V., Kubicek, C.P., 2011. Trichoderma: the genomics of opportunistic success. Nature Reviews 9, 749759

Duijff, B.J., Meijer, J.W., Bakker, P.A.H.M., Schippers, B., 1993. Siderophore-mediated competition for iron and induced resistance in the suppression of fusarium wilt of carnation by fluorescent Pseudomonas spp. European Journal of Plant Pathology 99, 277-289.

Glandorf, D.C.M., Brand, I., Bakker, P.A.H.M., Schippers, B., 1992. Stability of rifampicin resistance as a marker for root colonization studies of Pseudomonas putida in the field. Plant and Soil 147, 135-142.

Gould, W.D., Hagedorn, C., Bardinelli, T.R., Zablotowicz, R.M., 1985. New selective media for enumeration and recovery of fluorescent pseudomonads from various habitats. Applied and Environmental Microbiology 49, 28-32.

Guzmán, P., Ecker, J.R., 1990. Exploiting the triple response of Arabidopsis to identify ethylene-related mutants. The Plant Cell 2, 513-523.

Harish, S., Kavino, M., Kumar, N., Balasubramanian, P., Samiyappan, R., 2009. Induction of defense-related proteins by mixtures of plant growth promoting endophytic bacteria against Banana bunchy top virus. Biological Control 51, 1625.

Harman, G.E., 2011. Multifunctional fungal plant symbionts: new tools to enhance plant growth and productivity. The New Phytologist 189, 647-649.

Harman, G.E., Howell, C.R., Viterbo, A., Chet, I., Lorito, M., 2004a. Trichoderma species-opportunistic, avirulent plant symbionts. Nature Reviews 2, 43-56.

Harman, G.E., Petzoldt, R., Comis, A., Chen, J., 2004b. Interactions between Trichoderma harzianum strain T22 and maize inbred line Mo17 and effects of these interactions on diseases caused by Pythium ultimum and Colletotrichum graminicola. Phytopathology 94, 147-153.

Hase, S., Van Pelt, J.A., Van Loon, L.C., Pieterse, C.M.J., 2003. Colonization of Arabidopsis roots by Pseudomonas fluorescens primes the plant to produce higher levels of ethylene upon pathogen infection. Physiological and Molecular Plant Pathology 62, 219-226.

Hoagland, D.R., Arnon, D.I., 1950. The water-culture method for growing plants without soil. Bulletin Californian Agricultural Experimental Station 347, 36-39.

Jetiyanon, K., Kloepper, J.W., 2002. Mixtures of plant growth-promoting rhizobacteria for induction of systemic resistance against multiple plant diseases. Biological Control 24, 285-291.

Khan, J., Ooka, J.J., Miller, S.A., Madden, L.V., Hoitink, H.A.J., 2004. Systemic resistance induced by Trichoderma hamatum 382 in cucumber against Phytophthora crown rot and leaf blight. Plant Disease 88, 280-286.

King, E.O., Ward, M.K., Raney, D.E., 1954. Two simple media for the demonstration of pyocyanin and fluorescin. Journal of Laboratory and Clinical Medicine 44, 301-307.

Kloepper, J.W., Leong, J., Teintze, M., Schroth, M.N., 1980. Enhanced plant growth by siderophores produced by plant growth-promoting rhizobacteria. Nature 286, 885-886.

Kloepper, J.W., Tuzun, S., Kuć, J.A., 1992. Proposed definitions related to induced disease resistance. Biocontrol Science and Technology 2, 349-351.

Korolev, N., Rav David, D., Elad, Y., 2007. The role of phytohormones in basal resistance and Trichoderma-induced systemic resistance to Botrytis cinerea in Arabidopsis thaliana. BioControl 53, 667-683.

Latha, P., Anand, T., Prakasam, V., Jonathan, E.I., Paramathma, M., Samiyappan, R., 2011. Combining Pseudomonas, Bacillus and Trichoderma strains with organic amendments and micronutrient to enhance suppression of collar and root rot disease in physic nut. Applied Soil Ecology 49, 215-223.

Leeman, M., Ouden, F.M., Pelt, J.A., Cornelissen, C., Matamala-Garros, A., Bakker, P.A.H.M., Schippers, B., 1996. Suppression of fusarium wilt of radish by coinoculation of fluorescent Pseudomonas spp. and root-colonizing fungi. European Journal of Plant Pathology 102, 21-31.

Liu, L., Kloepper, J.W., Tuzun, S., 1995. Induction of systemic resistance in cucumber against Fusarium wilt by plant growth-promoting rhizobacteria. Phytopathology 85, 695-698.
Lorito, M., Woo, S.L., Harman, G.E., Monte, E., 2010. Translational research on Trichoderma: from 'omics to the field. Annual Review of Phytopathology 48 395-417.

Lugtenberg, B., Kamilova, F., 2009. Plant-growth-promoting rhizobacteria. Annual Review of Microbiology 63, 541-556.

Lutz, M.P., Wenger, S., Maurhofer, M., Defago, G., Duffy, B., 2004. Signaling between bacterial and fungal biocontrol agents in a strain mixture. FEMS Microbiology Ecology 48, 447-455.

Marx, J., 2004. The roots of plant-microbe collaborations. Science 304, 234-236.

Migocka, M., Papierniak, A., 2011. Identification of suitable reference genes for studying gene expression in cucumber plants subjected to abiotic stress and growth regulators. Molecular Breeding 28, 343-357.

Moreno, C.A., Castillo, F., González, A., Bernal, D., Jaimes, Y., Chaparro, M., González, C., Rodriguez, F., Restrepo, S., Cotes, A.M., 2009. Biological and molecular characterization of the response of tomato plants treated with Trichoderma koningiopsis. Physiological and Molecular Plant Pathology 74, 111-120.

Nawrath, C., Métraux, J., 1999. Salicylic acid induction-deficient mutants of Arabidopsis express PR-2 and PR-5 and accumulate high levels of camalexin after pathogen inoculation. The Plant Cell 11, 1393-1404.

Nubel, U., Engelen, B., Felske, A., Snaidr, J., Wieshuber, A., Amann, R.I., Ludwig, W. Backhaus, H., 1996. Sequence heterogeneities of genes encoding 16S rRNAs in Paenibacillus polymyxa detected by temperature gradient gel electrophoresis. Journal of Bacteriology 178, 5636-5643.

Pfaffl, M.W., 2001. A new mathematical model for relative quantification in realtime RT-PCR. Nucleic Acids Research 29, e45.

Pieterse, C.M.J., Van Wees, S.C.M., Hoffland, E., Van Pelt, J.A., Van Loon, L.C., 1996 Systemic resistance in Arabidopsis induced by biocontrol bacteria is independent of salicylic acid accumulation and pathogenesis-related gene expression. Plant Cell 8, 1225-1237.

Pieterse, C.M.J., van Wees, S.C.M., van Pelt, J.A., Knoester, M., Laan, R., Gerrits, H., Weisbeek, P.J., Van Loon, L.C., 1998. A novel signaling pathway controlling induced systemic resistance in Arabidopsis. Plant Cell 10, 1571-1580.

Pieterse, C.M.J., Van Pelt, J.A., Ton, J., Parchmann, S., Mueller, M.J., Buchala, A.J., Métraux, J.-P., Van Loon, L.C., 2000. Rhizobacteria-mediated induced systemic resistance (ISR) in Arabidopsis requires sensitivity to jasmonate and ethylene but is not accompanied by an increase in their production. Physiological and Molecular Plant Pathology 57, 123-134.

Pieterse, C.M.J., Van Pelt, J.A., Verhagen, B.W.M., Ton, J., Van Wees, S.C.M., LeonKloosterziel, K.M., Van Loon, L.C., 2003. Induced systemic resistance by plant growth promoting rhizobacteria. Symbiosis 35, 39-55.

Pieterse, C.M.J., Leon-Reyes, A., Van der Ent, S., Van Wees, S.C.M., 2009. Networking by small-molecule hormones in plant immunity. Nature Chemical Biology 5 308-316.

Pozo, M.J., Van Der Ent, S., Van Loon, L.C., Pieterse, C.M.J., 2008. Transcription factor MYC2 is involved in priming for enhanced defense during rhizobacteriainduced systemic resistance in Arabidopsis thaliana. The New phytologist 180 511-523.

Salas-Marina, M.A., Silva-Flores, M.A., Uresti-Rivera, E.E., Castro-Longoria, E. Herrera-Estrella, A., Casas-Flores, S., 2011. Colonization of Arabidopsis roots by Trichoderma atroviride promotes growth and enhances systemic disease resistance through jasmonic acid/ethylene and salicylic acid pathways. European Journal of Plant Pathology 131, 15-26.

Samuels, G.J., 2006. Trichoderma: systematics, the sexual state, and ecology. Phytopathology 96, 195-206.

Segarra, G., Jauregui, O., Casanova, E., Trillas, I., 2006. Simultaneous quantitative LCESI-MS/MS analyses of salicylic acid and jasmonic acid in crude extracts of Cucumis sativus under biotic stress. Phytochemistry 67, 395-401.

Segarra, G., Casanova, E., Bellido, D., Odena, M.A., Oliveira, E., Trillas, I., 2007. Proteome, salicylic acid, and jasmonic acid changes in cucumber plants inoculated with Trichoderma asperellum strain T34. Proteomics 7, 3943-3952.

Segarra, G., Van der Ent, S., Trillas, I., Pieterse, C.M.J., 2009. MYB72, a node of convergence in induced systemic resistance triggered by a fungal and a bacterial beneficial microbe. Plant Biology 11, 90-96.

Shanmugam, V., Kanoujia, N., Singh, M., Singh, S., Prasad, R., 2011. Biocontrol of vascular wilt and corm rot of gladiolus caused by Fusarium oxysporum $\mathrm{f}$. sp. gladioli using plant growth promoting rhizobacterial mixture. Crop Protection 30, 807-813.

Sheu, D.-S., Wang, Y.-T., Lee, C.-Y., 2000. Rapid detection of polyhydroxyalkanoateaccumulating bacteria isolated from the environment by colony PCR. Microbiology 146, 2019-2025.

Shoresh, M., Harman, G.E., 2008. The molecular basis of shoot responses of maize seedlings to Trichoderma harzianum T22 inoculation of the root: a proteomic approach. Plant Physiology 147, 2147-2163.

Shoresh, M., Yedidia, I., Chet, I., 2005. Involvement of jasmonic acid/ethylene signaling pathway in the systemic resistance induced in cucumber by Trichoderma asperellum T203. Phytopathology 95, 76-84.

Shoresh, M., Harman, G.E., Mastouri, F., 2010. Induced systemic resistance and plant responses to fungal biocontrol agents. Annual Review of Phytopathology 48, 21-43.

Stockwell, V.O., Johnson, K.B., Sugar, D., Loper, J.E., 2011. Mechanistically compatible mixtures of bacterial antagonists improve biological control of fire blight of pear. Phytopathology 101, 113-123.

Van der Ent, S., Verhagen, B.W., Van Doorn, R., Bakker, D., Verlaan, M.G., Pel, M.J., Joosten, R.G., Proveniers, M.C., Van Loon, L.C., Ton, J., Pieterse, C.M.J., 2008. MYB72 is required in early signaling steps of rhizobacteria-induced systemic resistance in Arabidopsis. Plant Physiology 146, 1293-1304. 
Van der Ent, S., Van Hulten, M., Pozo, M.J., Czechowski, T., Udvardi, M.K., Pieterse, C.M.J., Ton, J., 2009a. Priming of plant innate immunity by rhizobacteria and beta-aminobutyric acid: differences and similarities in regulation. The New Phytologist 183, 419-431.

Van der Ent, S., Van Wees, S.C., Pieterse, C.M.J., 2009b. Jasmonate signaling in plant interactions with resistance-inducing beneficial microbes. Phytochemistry 70 1581-1588.

Van Loon, L.C., Bakker, P.A.H.M., Pieterse, C.M.J., 1998. Systemic resistance induced by rhizosphere bacteria. Annual Review of Phytopathology 36, 453-483.

Van Wees, S.C.M., Pieterse, C.M.J., Trijssenaar, A., Van 't Westende, Y.A., Hartog, F. Van Loon, L.C., 1997. Differential induction of systemic resistance in Arabidopsis by biocontrol bacteria. Molecular Plant-Microbe Interactions 10, 716-724.

Van Wees, S.C.M., Luijendijk, M., Smoorenburg, I., Van Loon, L.C., Pieterse, C.M.J. 1999. Rhizobacteria-mediated induced systemic resistance (ISR) in Arabidopsis is not associated with a direct effect on expression of known defense-related genes but stimulates the expression of the jasmonate-inducible gene Atvsp upon challenge. Plant Molecular Biology 41, 537-549.

Van Wees, S.C.M., De Swart, E.A.M., Van Pelt, J.A., Van Loon, L.C., Pieterse, C.M.J., 2000. Enhancement of induced disease resistance by simultaneous activation of salicylate- and jasmonate-dependent defense pathways in Arabidopsis thaliana. In: Proceedings of the National Academy of Sciences of the United States of America 97, 8711-8716.
Van Wees, S.C.M., Van der Ent, S., Pieterse, C.M.J., 2008. Plant immune responses triggered by beneficial microbes. Current Opinion in Plant Biology 11, 443-448.

Vinale, F., Sivasithamparam, K., Ghisalberti, E.L., Marra, R., Woo, S.L., Lorito, M., 2008. Trichoderma-plant-pathogen interactions. Soil Biology and Biochemistry 40, 1-10.

Viterbo, A., Wiest, A., Brotman, Y., Chet, I., Kenerley, C., 2007. The 18mer peptaibols from Trichoderma virens elicit plant defence responses. Molecular Plant Pathology 8, 737-746.

Wan, H., Zhao, Z., Qian, C., Sui, Y., Malik, A.A., Chen, J., 2010. Selection of appropriate reference genes for gene expression studies by quantitative real-time polymerase chain reaction in cucumber. Analytical Biochemistry 399, 257-261.

White, T.J., Bruns, T., Lee, S., Taylor, J., 1990. Amplification and direct sequencing of fungal ribosomal RNA genes for phylogenetics. PCR Protocols a Guide to Methods and Applications. Academic Press, San Diego California, USA, pp. 315322.

Yoshioka, Y., Ichikawa, H., Naznin, H.A., Kogure, A., Hyakumachi, M., 2012. Systemic resistance induced in Arabidopsis thaliana by Trichoderma asperellum SKT-1, a microbial pesticide of seedborne diseases of rice. Pest Management Science 68, 60-66.

Zang, W., Dick, W.A., Hoitink, H.A.J., 1996. Compost-induced systemic acquired resistance in cucumber to Pythium root rot and anthracnose. Phytopathology 86, 1066-1070. 